\title{
Rheological Properties and Shelf Life of Soft Cheese Made from Camel Milk Using Camel Chymosin
}

\author{
Mohammed $\mathrm{S}^{1 *}$, Eshetu $\mathrm{M}^{2}$, Tadesse $\mathrm{Y}^{2}$ and Hailu $\mathrm{Y}^{2}$ \\ ${ }^{1}$ Department of Animal Sciences, Bonga University, Ethiopia \\ ${ }^{2}$ School of Animal and Range Sciences, Haramaya University, Ethiopia
}

Submission: February 06, 2019; Published: March 12, 2019

*Corresponding author: Seid Mohammed, Department of Animal Sciences, Bonga University, P. O. Box: 334, Bonga, Ethiopia

\begin{abstract}
This study was aimed to investigate the shelf life and rheological properties of soft cheese made from camel milk using streptococcus thermophilus (ST1-12) starter culture and camel chymosin as coagulant; and stored at a temperature of $4 \pm 1^{\circ} \mathrm{C}$ and $18 \pm 1^{\circ} \mathrm{C}$ for $1,8,15$ and 22 days. The results revealed that the protein, fat and total solids content of the cheese significantly $(\mathrm{P}<0.05)$ increased during storage. Storage temperature significantly $(\mathrm{P}<0.05)$ affect the $\mathrm{pH}$, titratable acidity, protein and fat content of cheese. Cheese sample kept at $18 \pm 1^{\circ} \mathrm{C}$ was significantly $(\mathrm{P}<0.05)$ higher in total bacterial count $(6.79 \mathrm{log} \mathrm{cfu} / \mathrm{g})$, coliform count $(7.21 \mathrm{log} \mathrm{cfu} / \mathrm{g})$, yeast and mould counts $(6.41 \mathrm{log} \mathrm{cfu} / \mathrm{g})$ than cheese sample kept at $4 \pm 1^{\circ} \mathrm{C}$ which is $4.76 \mathrm{log} \mathrm{cfu} / \mathrm{g}, 4.09 \mathrm{log} \mathrm{cfu} / \mathrm{g}$ and $4.84 \mathrm{log} \mathrm{cfu} / \mathrm{g}$ of total bacterial count, coliform count and yeast and mould counts, respectively. Firmness of the cheeses were significantly $(\mathrm{P}<0.05)$ affected by storage temperature and storage time. The firmness of the cheese sample stored at $4 \pm 1^{\circ} \mathrm{C}$ significantly $(\mathrm{P}<0.05)$ increased from $3.77 \pm 0.17 \mathrm{~N}$ on day one to $6.67 \pm 0.12 \mathrm{~N}$ on day 22 . Cheese stored at $4 \pm 1^{\circ} \mathrm{C}$ had acceptable shelf life till days 22 of storage period, but cheese that kept at $18 \pm 1^{\circ} \mathrm{C}$ had a maximum shelf stability of 6 days without losing consumer acceptability. Therefore, soft cheese made from camel milk can be stored up to 22 days at lower temperature $\left(4 \pm 1^{\circ} \mathrm{C}\right)$ and for 6 days at $18 \pm 1^{\circ} \mathrm{C}$. Therefore, a resource poor society produces without cooling can store the soft cheese made from camel milk at $18 \pm 1^{\circ} \mathrm{C}$ for about 6 days.

Keywords: Camel milk; Rheology; Shelf life; Soft cheese; Storage temperature

Abbrevations: ANOVA: Analysis of Variance; AOAC: Association of Official Analytical Chemistry; $\beta$-casein: Beta casein; CaCl2: Calcium Chloride; CC: Coliform Count; CFU: Colony Forming Units; CRD: Completely Randomized Design; CSA: Central Statistical Agency; FAO: Food and Agriculture Organization of the United Nations; FPC: Fermented Produced Chymosin; GLM: General Liner Model; GMO: Genetically Modified Organism; к-casein: Kappa casein; IMCU: International Milk Clotting Units; LAB: Lactic Acid Bacteria; LSD: Least Significant Difference; PCA: Plate Count Agar; PDA: Potato Dextrose Agar; pH: Power of Hydrogen; SAS: Statistical Analysis System; TA: Titratable Acidity; TB: Total Bacterial Count; TPA: Textural Profile Analysis; YMC: Yeast and Mould Count
\end{abstract}

\section{Introduction}

Ethiopia possesses over 4.5 million camels (Camelus dromedaries) and is the second in Africa in camel population [1]. Camels are kept among other animals, mainly for milk production in the pastoral areas. A healthy camel on good feed can produce up to 12,000 liter of milk per lactation [2]. Cheese is a dairy product with best nutritional value and health care function, and it is popular in many countries in the world with good taste and diverse flavor [3]. Thousands of types of cheese are produced in the world but their styles, textures and flavors depend on the origin of milk, animal's diet, butterfat content, bacteria and mold, the processing, and aging conditions. Cheese and other dairy products are produced from cow and small ruminant's milk traditionally but not easy for camel milk [4]. Processing of camel milk into different product including cheese were reported to be difficult due to the inherent properties of camel milk including scarce presence of $\kappa$-casein, absence of $\beta$-lactoglobulins; and other different factors [5], however there are successful trials made using camel chymosin [6,7] after the advent for camel chymosin [8]. However, the shelf stability of soft cheese made from camel milk at different temperature is not addressed and lacking in the reports made so far.

The shelf life of non-sterile dairy products, including pasteurized milk, soft cheese, and some types of yogurt and fermented milk products is generally limited to one to three weeks depending upon the quality of the raw ingredients, processing conditions, and post processing handling [9]. Although there have been several studies focused on the shelf life and textural properties of cheese made from cow milk [10], similar studies on soft cheese 
made from camel milk are scarce and also the technology of camel milk cheese production is in its infant stage. Therefore, this study is designed to evaluate the rheological properties and shelf life of soft cheese made from camel milk stored at different temperature.

\section{Materials and Methods}

\section{Materials}

Camel milk was collected from Errer valley, Babile district of eastern Ethiopia. Camel Chymosin (ChyMAx®) with 1000 International Milk Clotting Units (IMCU)/ml and starter cultures streptococcus thermophilis (STI-12) were donated from Chr/Hansen, Denmark. Cheese vat (FT20, Armfield, UK) used for cheese making, and MilkoScan (MilkoScan ${ }^{\text {TM }}$ FT1, Foss, Denmark) was used to analyze chemical composition of the raw milk. Texture analyzer (Micro stable TA-XT Plus Texture Analyzer) used for rheological study. All other chemicals used were analytical grades. The culture media using for microbial analysis were obtained from Oxoid Ltd. (Basingstoke, Hampshire, England).

\section{Sample Collection}

Milk samples were collected from pastorally managed camels during winter season (mid-December to mid-February) from Errer vally of eastern Ethiopia in which surplus of camel milk available. The milk was collected by hand milking of camels which are in the mid stage of lactation (3 to 7 month). Then, the samples were labeled and transported in icebox, in the same day to the Dairy Technology Laboratory of Haramaya University for cheese making and laboratory analysis. The experiment was conducted in triplicate.

\section{Experimental Design}

The experiment was layed out by 2 by 4 factorial arrangements with completely randomized design (CRD) using analysis of variance (ANOVA) technique. The factors are two levels of storage temperature (i.e. $18 \pm 1^{\circ} \mathrm{C}$ and $4 \pm 1^{\circ} \mathrm{C}$ ) and four levels of storage pe$\operatorname{riod}\left(\right.$ i.e. $1^{\text {st }}, 8^{\text {th }}, 15^{\text {th }}$ and $22^{\text {nd }}$ day).

\section{Preparation of soft cheese}

Soft cheese was made according to the procedure Mehaia [5]. Camel milk was pasteurized at $65^{\circ} \mathrm{C}$ for $30 \mathrm{~min}$ and cooled to $40^{\circ} \mathrm{C}$ for inoculation of starter culture (ST1-12). CaCl2 of $0.03 \mathrm{~g} / \mathrm{L}$ of milk was added and stirred for 30 minutes. One ml per liter of starter culture (ST1-12) was added to the milk and after 30 minutes camel chymosin of $50 \mathrm{IMCU} / \mathrm{L}$ of milk was inoculated and then the milk left undisturbed for 120 minutes for coagulation. The resulting coagulum was cut approximately into $\sim 1 \mathrm{~cm}^{3}$ using sterile spoon and left for ten minutes to facilitate drainage. The cheese curd was scooped into mould. Then the cheese curd was kept overnight draining at $18 \pm 1^{\circ} \mathrm{C}$ to separate the curd from the whey. Finally, the cheese curd was placed in clean container for analysis.

\section{Physicochemical Properties of Soft Camel Milk Cheese}

The $\mathrm{pH}$ of milk samples was measured using digital $\mathrm{pH}$ meter (Model 51950; Hach, Loveland, USA) after calibrating with fresh standard buffer solutions of $\mathrm{pH} 4.0$ and 7.0. The gross composition of camel milk i.e. fat, solids-not-fat (SNF), protein, total solids and lactose were determined using MilkoScan (MilkoScan ${ }^{\mathrm{TM}}$ FT1, Foss, Denmark). The physicochemical properties ( $\mathrm{pH}$, titratable acidity, total solids, ash, protein and fat) of soft cheese were analyzed following standard procedures [11].

\section{Microbiological Examination of Soft Cheese}

Microbiological quality analyses of samples were made according to Ousman [12]. Suitable dilutions were used for the determination of total bacterial count (TBC), coliform count (CC) and yeasts and moulds count (YMC). All media obtained in a powder form was prepared according to the guidelines given by the manufacturers. Media and pipette tips were also sterilized by autoclave (Astell, Model AAJ040) at $121^{\circ} \mathrm{C}$. The glass wares such as petri dishes, test tubes, flasks, pipettes and bottles were also sterilized in oven at $135^{\circ} \mathrm{C}$ for 30 minutes. Plate count agar medium used for determining the TBC by incubated at $33^{\circ} \mathrm{C}$ for 48 hours. Violet red bile agar used to determine CC after incubated at $33^{\circ} \mathrm{C}$ for 24 hours, and potato dextrose agar used for YMC determination after incubating at $25^{\circ} \mathrm{C}$ for 5 days. The plate was examined by counting the colonies using a colony counter. Plates containing between 30 300 colonies were conjured to compute the colony forming units (cfu) per gram.

\section{Rheological Properties of Soft Camel milk Cheese}

The rheological characteristics of the experimental soft cheese were determined by using TA-XT Plus texture analyzer with a load cell of $30 \mathrm{~kg}$ (Vienna count, surrey GU7 1 YL, UK). Cheese samples with $18 \mathrm{~mm}$ diameter and $20 \mathrm{~mm}$ height were used for measurements. Compression test was performed using $\mathrm{P} / 25$ probe $(25 \mathrm{~mm}$ diameter Aluminum cylinder), test speed of $0.83 \mathrm{~mm} / \mathrm{s}$ and compression was made to $75 \mathrm{~g} / 100 \mathrm{~g}$ of the original sample height. The texture variables, hardness (expressed as Newton, N) and adhesiveness (expressed as Newton second, Ns), were calculated as described by Bourne [13]. All measurements were done in duplicate.

\section{Statistical Data Analysis}

The rheological properties and shelf life data obtained was analyzed using General Linear Model procedure of SAS version 9.1 [14]. Microbial data were first transformed to logarithmic values ( $\log 10)$ prior to statistical analysis. Mean value was compared using Tukey test and the differences among the means were determined a significance level of $\mathrm{p}<0.05$.

\section{Results and Discussion}

\section{Physicochemical Properties of soft cheese}

The physicochemical properties of camel milk used for cheese making were presented in Table 1 . According to the report of Alaoui [15] the averages values for proximate composition of camel milk samples were $2.72 \pm 0.64 \mathrm{~g} / 100 \mathrm{~g}$ fat; $4.37 \pm 0.61 \mathrm{~g} / 100 \mathrm{~g}$ lactose; $2.55 \pm 0.27 \mathrm{~g} / 100 \mathrm{~g}$ proteins; $0.87 \pm 0.07 \mathrm{~g} / 100 \mathrm{~g}$ ash and $10.42 \pm 1.04 \mathrm{~g} / 100 \mathrm{~g}$ total solids. The observed difference in chemical composition could be explained by the effect of various factors 
such as camel breed, stage of lactation, age and health status, herd management practices and environmental conditions [16].

Table 1: Physicochemical composition of camel milk used for cheese making.

\begin{tabular}{|c|c|}
\hline Physicochemical Parameter & Camel Milk (g/100 g) \\
\hline $\mathrm{pH}$ & $6.63 \pm 0.23$ \\
\hline Titratable acidity (\%) & $0.43 \pm 0.04$ \\
\hline Total solid & $10.76 \pm 1.00$ \\
\hline SNF & $7.69 \pm 0.40$ \\
\hline Lactose & $4.75 \pm 0.26$ \\
\hline Fat & $3.01 \pm 0.58$ \\
\hline Protein & $2.48 \pm 0.11$ \\
\hline
\end{tabular}

Values in the table are mean \pm standard deviation of three replication $(n=3), S N F=$ sold-not-fat.

Table 2: Effect of storage period and storage temperature on physicochemical properties of soft cheese.

\begin{tabular}{|c|c|c|c|c|c|c|}
\hline \multirow{2}{*}{ Physicochemical Composition } & \multirow{2}{*}{ Storage Temperature } & \multicolumn{4}{|c|}{ Storage Period (Days) } \\
\cline { 2 - 6 } & & $\mathbf{1}$ (control) & $\mathbf{8}$ & $\mathbf{1 5}$ & $\mathbf{2 2}$ \\
level
\end{tabular}

Means with different superscript letters within the same row for $18 \pm 1^{\circ} \mathrm{C}$ and $4 \pm 1{ }^{\circ} \mathrm{C}$ indicated significantly different $(\mathrm{P}<0.05)$; Values in the table are mean \pm standard deviation of $\mathrm{n}=3, \mathrm{TA}=$ Titratable acidity; sign level= level of significant, $\mathrm{ns}=$ non-significant; * $=$ significant at $5 \mathrm{~g} / 100 \mathrm{~g}$ of probability level.

The protein content of cheese samples stored at $4 \pm 1^{\circ} \mathrm{C}$ were not significantly higher than those stored at $18 \pm 1^{\circ} \mathrm{Cat}$ day 1 and 8 but at days 15 the protein contents of the $4 \pm 1^{\circ} \mathrm{C}$ samples were significantly higher in values than the $18 \pm 1^{\circ} \mathrm{C}$ stored cheese sample. These findings were in line with the work of Bilal [17] who stated that protein content of cheese samples stored at $4 \pm 1^{\circ} \mathrm{C}$ were higher than those stored at $18 \pm 1^{\circ} \mathrm{C}$. This result also agrees with the findings of Abdel Razig [18] who reported that the protein contents of cheese increased during aging due to decrease in moisture contents. At day 15, the decrease in protein content of the cheese sample stored at room temperature might be due to the growth of proteolytic bacteria and absorption of high level of moisture by the curd. That further accelerated microbiological growth which leads to degradation of protein content, while the high protein content $(22.98 \pm 0.16 \mathrm{~g} / 100 \mathrm{~g})$ of the sample in the $4 \pm 1^{\circ} \mathrm{C}$ were possibly attributed to low moisture content and high acidity in the curd which reduce proteolysis (Table 2).
Total protein content of the cheese samples stored at $18 \pm 1^{\circ} \mathrm{C}$ were significantly $(\mathrm{P}<0.05)$ increased from day one to day 15 , then decreased at day 22 (Table 2). The maximum and minimum value of protein content was recorded at day one and day 15 i.e. $24.24 \pm 0.16$ and $16.5 \pm 0.12 \mathrm{~g} / 100 \mathrm{~g}$, respectively for the cheese sample stored at $18 \pm 1^{\circ} \mathrm{C}$. The protein contents of the cheese samples kept at $4 \pm 1^{\circ} \mathrm{C}$ also significantly $(\mathrm{P}<0.05)$ increased from $17.49 \pm 0.22 \mathrm{~g} / 100 \mathrm{~g}$ at day one to $22.98 \pm 0.16 \mathrm{~g} / 100 \mathrm{~g}$ on day 15 then the values decreased to $18.54 \pm 0.16 \mathrm{~g} / 100 \mathrm{~g}$ at day 22 of storage. The change in protein content indicated that there is moisture loss as result total solid increase, and protein content also increase when storage time progressed until day 15; then after day 15, proteolysis happened, which degraded protein in to soluble fraction [12] thus resulted the amount of protein decrease at day 22 of storage.

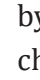
cheese samples stored at $4 \pm 1^{\circ} \mathrm{C}$ significantly $(\mathrm{P}<0.05)$ increased from $20.00 \pm 0.70 \mathrm{~g} / 100 \mathrm{~g}$ at day one to $28.50 \pm 0.50 \mathrm{~g} / 100 \mathrm{~g}$ at day 22 , while fat content of cheese samples stored at $18 \pm 1^{\circ} \mathrm{C}$ were not significantly ( $p>0.05)$ affected as storage time progressed. This might be due to the loss of moisture content during storage and increase in total solid contents. This result agrees with the finding of Bilal [17] that reported as fat content increase during storage of cheese which attributed less lipolysis and small loss of fat in the whey. The decrease in fat content associated with the relative humidity of the storage conditions, which could have stimulated the activity of lipase to degraded fat into free fatty acids and glycerol, resulting in reduction in total fat content of the product [19]. Significant variations were found in fat contents between cheese sample stored at $18 \pm 1^{\circ} \mathrm{C}$ and $4 \pm 1^{\circ} \mathrm{C}$ from 22 days of storage (Table 2). 
Total solid (TS) content of cheese affected by both storage temperature and storage period (Table 2). TS of cheese sample kept at $4 \pm 1^{\circ} \mathrm{C}$ had increased significantly $(\mathrm{p}<0.05)$ from day one to day 22 (Table 2). Whereas samples stored at $18 \pm 1^{\circ} \mathrm{C}$ were not significantly affected by storage temperature, but significant variation were observed between two storage temperatures at day 22 . This increase in TS might be due to continuous loss of moisture from the curd as results of lactic acid development which causes curd contraction. The findings are in accordance with the work of Ousman [12] who found that the TS content of the white soft cheese increased during storage, and at high temperature caused desirable physical condition of curd that permitted the whey to filter off through and among particles.

The increase in TS of sample stored at $4 \pm 1^{\circ} \mathrm{C}$ compared to those stored at $18 \pm 1^{\circ} \mathrm{C}$ conditions is in line with the finding reported by Bilal [17]. Increase in total solid leads strong curd formation, which increase elasticity and change in texture so that it is more compact and has fewer opening and altered bacterial flora. These findings are in line with the work of Walstra [20] who stated TS content of the cheese stored at $4 \pm 1^{\circ} \mathrm{C}$ were higher in comparison with those stored at $18 \pm 1^{\circ} \mathrm{C}$. The increase in total solids contents of cheese stored at $4 \pm 1^{\circ} \mathrm{C}$ might be due to inhibition of proteolytic and lipolytic activities of microorganisms by low storage temperature.

The change in titratable acidity (g/100g lactic acid) of soft cheese stored at $18 \pm 1^{\circ} \mathrm{C}$ increased significantly $(\mathrm{P}<0.05)$ with storage time. The titratable acidity of cheese samples stored at $18 \pm 1^{\circ} \mathrm{C}$ was higher than those sample kept at $4 \pm 1^{\circ} \mathrm{C}$. This finding agrees with El Owni \& Hamed [21] who reported that the higher acidity of the cheese stored at $18 \pm 1^{\circ} \mathrm{C}$ may be attributed to the increased level of lactic acid due to the activation and growth of predominating lactic acid bacteria with increases in temperature. The higher titratable acidity found in this study is comparable with the study of Bilal, Nuser \& Perveen [17,22,23]. While, the lower acidity of cheese samples stored at $4 \pm 1^{\circ} \mathrm{C}$ might be explained by the fact that low temperature inhibited growth and activity of lactic acid forming bacteria consequently lowering the rate of acid development, and also utilization of lactic acid by other micro flora during storage. El Owni \& Hamed [21] added that the titratable acidity of cheese samples stored at $18 \pm 1^{\circ} \mathrm{C}$ was higher as compared to those stored at $4 \pm 1^{\circ} \mathrm{C}$. Storage temperature and storage period did not significantly $(\mathrm{P}>0.05)$ affect ash contents of the cheese samples.

\section{Change in Microbial Quality of Soft Cheese during Storage}

Total bacterial count, coliform count, yeast and mold counts increased significantly $(\mathrm{p}<0.05)$ during storage periods of soft cheese at $18 \pm 1^{\circ} \mathrm{C}$. The increase in the counts of the aforementioned groups of microorganisms led to a drop in the $\mathrm{pH}$ and rise in the titratable acidity. But, at $4 \pm 1^{\circ} \mathrm{C}$ no significant ( $\mathrm{p}>0.05$ ) variation were observed during storage of soft cheese sample in total bacterial count, coliform count or yeast and mold counts.

\section{Total Bacterial Count}

The effect of storage period and storage temperature on microbiological quality of soft cheese is indicated in Table 3. Total bacterial counts (log $\mathrm{CFU} / \mathrm{g}$ ) of soft cheese was significantly $(\mathrm{P}<0.05)$ increase with the advance in storage period in cheese sample stored at $18 \pm 1^{\circ} \mathrm{C}$. At $18 \pm 1^{\circ} \mathrm{C}$ the number of total bacteria increased from day one to day 22 , which is maximum value, whereas those cheese sample stored at $4 \pm 1^{\circ} \mathrm{C}$ were not significantly $(\mathrm{P}>0.05)$ affected by storage period (Table 3$)$. Total bacterial count (TBC) of cheese stored at $4 \pm 1^{\circ} \mathrm{C}$ were significantly higher $(\mathrm{P}<0.05)$ at day 15 and day 22 than those stored at $4 \pm 1^{\circ} \mathrm{C}$. The increase in TBC could be due to rapid growth of microorganisms during storage time. This may be due to $18 \pm 1^{\circ} \mathrm{C}$ is conducive environment for most bacterial multiplication and growth. But $4 \pm 1^{\circ} \mathrm{C}$ inhibits the growth and multiplication of most bacteria except some psychotropic bacteria.

Table 3: Effect of storage period and storage temperature on soft cheese microbiology.

\begin{tabular}{|c|c|c|c|c|c|c|}
\hline \multirow[b]{2}{*}{ Microbial count (log $\mathrm{cfu} / \mathrm{g}$ ) } & \multirow[b]{2}{*}{ Storage Temperature } & \multicolumn{5}{|c|}{ Storage Period (Days) } \\
\hline & & 1 (control) & 8 & 15 & 22 & Sign. levels \\
\hline \multirow{2}{*}{ TBC } & $18 \pm 1^{\circ} \mathrm{C}$ & $5.04 \pm 0.51^{c}$ & $6.34 \pm 0.36^{\mathrm{bc}}$ & $7.62 \pm 0.36^{\mathrm{ab}}$ & $8.59 \pm 0.36^{\mathrm{a}}$ & \multirow{2}{*}{$*$} \\
\hline & $4 \pm 1^{\circ} \mathrm{C}$ & $4.62 \pm 0.51^{c}$ & $5.35 \pm 0.36^{c}$ & $4.88 \pm 0.36^{c}$ & $5.19 \pm 0.39^{c}$ & \\
\hline \multirow[t]{2}{*}{$\mathrm{CC}$} & $18 \pm 1^{\circ} \mathrm{C}$ & $5.56 \pm 0.81^{\mathrm{bc}}$ & $6.46 \pm 0.42^{\mathrm{ab}}$ & $6.55 \pm 0.42^{\mathrm{ab}}$ & $8.78 \pm 0.42^{\mathrm{a}}$ & \multirow{2}{*}{$*$} \\
\hline & $4 \pm 1^{\circ} \mathrm{C}$ & $5.48 \pm 0.59^{\mathrm{bc}}$ & $4.29 \pm 0.42^{\mathrm{bc}}$ & $2.99 \pm 0.42^{c}$ & $3.11 \pm 0.42^{\mathrm{c}}$ & \\
\hline \multirow[t]{2}{*}{ YMC } & $18 \pm 1^{\circ} \mathrm{C}$ & $4.94 \pm 0.43 b c$ & $6.08 \pm 0.30 \mathrm{ab}$ & $7.94 \pm 0.3 a$ & $6.68 \pm 0.30 \mathrm{ab}$ & * \\
\hline & $4 \pm 1^{\circ} \mathrm{C}$ & $5.29 \pm 0.43^{\mathrm{bc}}$ & $4.80 \pm 0.30^{\mathrm{bc}}$ & $3.92 \pm 0.30^{c}$ & $5.37 \pm 0.3^{\mathrm{bc}}$ & \\
\hline
\end{tabular}

Means values having different superscript letters within the same rows for each microbial count indicates significantly different $(P<0.05)$, Values in the table are mean \pm standard deviation of $n=3, Y M C=$ Yeast and mold count, $C C=$ Coliform count, $T B C=$ Total bacterial count, $C$ fu $/ g=$ colony forming unit per gram, sign level= level of significant, ${ }^{*}=$ highly significant at $5 \%$ of probability level.

\section{Coliform Count}

Storage temperature and storage period significantly $(\mathrm{P}<0.05)$ affect coliform counts of cheese samples during storage (Table 3).
The coliform counts of cheese sample kept at $18 \pm 1^{\circ} \mathrm{C}$ were significantly $(\mathrm{P}<0.05)$ increase from $5.56 \pm 0.81 \log \mathrm{cfu} / \mathrm{g}$ at day one to $8.78 \pm 0.42 \log \mathrm{cfu} / \mathrm{g}$ at day 22 . While, those cheese samples stored 
at $4 \pm 1^{\circ} \mathrm{C}$ were not significantly $(\mathrm{P}>0.05)$ affected even though the number decreased as storage time increased, because of the high level of acidity in the cheese samples which contributed in suppression of their growth [3]. The increase in coliform counts were possibly due to decreased acidity of the cheese as a result of the activity of lactic acid bacteria inhibited and some alkaline compound produced [20]. This might be by the rapid multiplication of the microbes at $18 \pm 1^{\circ} \mathrm{C}$ faster than $4 \pm 1^{\circ} \mathrm{C}$, which regressed their growth.

\section{Yeast and Mold Count}

The storage condition significantly $(\mathrm{P}<0.05)$ affect yeast and mould count of soft cheese. Yeasts and moulds of cheese stored at $18 \pm 1^{\circ} \mathrm{C}$, at day one was lower than those of day 22 . Yeasts and moulds of the cheese kept at $18 \pm 1^{\circ} \mathrm{C}$ were increased from day one $(4.94 \pm 0.43 \mathrm{log} \mathrm{cfu} / \mathrm{g})$ till day $15(7.94 \pm 0.3 \mathrm{log} \mathrm{cfu} / \mathrm{g})$. The growth of yeast and moulds at $18 \pm 1^{\circ} \mathrm{C}$ could be due to the favorable conditions, which encourage their growth. These results were in accordance with the findings of Shobha [24] who reported that yeast counts cheese increased from $5.39 \mathrm{log} \mathrm{cfu} / \mathrm{g}$ at day one to $8.69 \mathrm{log}$ $\mathrm{cfu} / \mathrm{g}$ at day 120 then the count decreased. The increase in yeast and mould count during storage might be attributed to the high acidity of the cheese which improved their growth [25].

Generally, samples stored at $4 \pm 1^{\circ} \mathrm{C}$ had better quality than those samples stored at $18 \pm 1^{\circ} \mathrm{C}$ especially in terms of microbial count. Samples stored at $18 \pm 1^{\circ} \mathrm{C}$ deteriorate and had shelf life of approximately 5 to 6 days, while other cheese sample stored at $4 \pm 1^{\circ} \mathrm{C}$ had a good score at day 22 storage periods. The yeast and mould count of the soft cheese less than $3 \mathrm{log} \mathrm{cfu} / \mathrm{g}$ are acceptable as prescribed by the International Microbiological Standards Recommended limit for food safety [24]. However, the result from the current study were higher than this limit, which have minimum and maximum values of $3.92 \pm 0.3 \mathrm{log} \mathrm{cfu} / \mathrm{g}$ and $7.94 \pm 0.3 \mathrm{log} \mathrm{cfu} / \mathrm{g}$, respectively at both storage temperature; that leads to grade the product was poor in Yeast and mould count in both storage temperature. However, to grade thus storage temperature as unsafe, it needs to evaluate the specific moulds that could have spoilage/ pathogens to the product as well as to consumers.

\section{Textural Analysis of Soft Cheese During Storage}

Firmness of cheese significantly $(\mathrm{P}<0.05)$ affected by both storage temperatures and storage periods. Firmness of cheese sample stored at $4 \pm 1^{\circ} \mathrm{C}$ significantly $(\mathrm{P}<0.05)$ increased from 8 to 22 days of storage (Table 4 ). The observed increases were probably due to decrease in moisture content of the sample. This is because water molecules within the three-dimensional protein matrix weaken the network structure, and, consistency of the protein matrix increases result infirm products [26]. Due to moisture loss, the product become slightly thicker however, body and texture score were no much influenced with increase in storage period. While, cheese stored at $18 \pm 1^{\circ} \mathrm{C}$ increase significantly $(\mathrm{P}<0.05)$ till day 15 then gradually decrease at day 22. The decreased in firmness of cheese was probably due to further breakdown of casein into small peptides that resulted the cheese texture to become softer in during storage [27]. Adhesiveness of cheese sample stored at both $4 \pm 1^{\circ} \mathrm{C}$ and $18 \pm 1^{\circ} \mathrm{C}$ were significantly $(\mathrm{P}<0.05)$ increased as storage time increased (Table 4). The difference found in adhesiveness may be linked to cheese $\mathrm{pH}$, degree proteolysis, and the polar characteristics of fat and protein fractions. Increasing of storage temperature from 0 to $15^{\circ} \mathrm{C}$ resulted in a decrease in the level of intact casein, and an increase in water binding capacity of the curd, which leads to decrease in adhesiveness of cheese [28-31].

Table 4: Effect of storage period and storage temperature on firmness $(\mathrm{N})$ and adhesiveness (Ns) of soft cheese.

\begin{tabular}{|c|c|c|c|c|c|c|}
\hline \multirow{2}{*}{ Texture Parameter } & \multirow{2}{*}{ Storage Temperature } & \multicolumn{5}{|c|}{ Storage Period (days) } \\
\hline & & 1 & 8 & 15 & 22 & Sign. level \\
\hline \multirow{2}{*}{ Firmness } & $18 \pm 1^{\circ} \mathrm{C}$ & $3.57 \pm 1.07^{\mathrm{cd}}$ & $3.69 \pm 0.56^{\mathrm{d}}$ & $4.46 \pm 0.55^{c}$ & $4.38 \pm 0.46^{c}$ & * \\
\hline & $4 \pm 1^{\circ} \mathrm{C}$ & $3.77 \pm 1.07^{\mathrm{cd}}$ & $4.16 \pm 0.66^{\text {cd }}$ & $5.28 \pm 0.56^{\mathrm{b}}$ & $6.67 \pm 0.46^{\mathrm{a}}$ & $*$ \\
\hline \multirow{2}{*}{ Adhesiveness } & $18 \pm 1^{\circ} \mathrm{C}$ & $0.008 \pm 0.001^{\mathrm{c}}$ & $0.26 \pm 0.13^{b}$ & $0.75 \pm 0.015^{\mathrm{ab}}$ & $0.75 \pm 0.015^{\mathrm{ab}}$ & * \\
\hline & $4 \pm 1^{\circ} \mathrm{C}$ & $0.12 \pm 0.1^{\mathrm{b}}$ & $0.64 \pm 0.13^{\mathrm{b}}$ & $1.06 \pm 0.13^{\mathrm{a}}$ & $0.77 \pm 0.13^{\mathrm{ab}}$ & * \\
\hline
\end{tabular}

Means values having different superscript letters within the same rows for each textural value indicates significantly different $(P<0.05)$, Values in the table are mean \pm standard deviation of $n=3$, sign level= level of significant, * $=$ highly significant at $5 \%$ of probability level.

\section{Conclusion}

The Physicochemical properties of cheese (i.e. total solids, fat and titratable acidity) increased win increase in storage time. Both firmness and adhesiveness of soft cheese made from camel milk were significantly affected by storage temperature and storage period. Microbiological quality of the cheese depends on storage temperature, that a higher count of total bacteria, coliform and yeast and mould is noted at temperature of $18 \pm 1^{\circ} \mathrm{C}$ of storage. Soft cheese storage at temperature of $4 \pm 1^{\circ} \mathrm{C}$ had acceptable total bacteria counts. During storage time of 22 days and these storage at $18 \pm 1^{\circ} \mathrm{C}$ had 6 days to stability. Firmness of soft cheese was increased at both storage temperatures but in later time the firmness is decreased. Adhesiveness of cheese sample stored at refrigerated temperature was significantly increased as storage time progressed. 


\section{Acknowledgement}

The authors are grateful to the Ministry of Education and Haramaya University for the study grant.

\section{Conflict of interest}

There is no conflict of interest

\section{References}

1. Shapiro BI, Getachew Gebru, Solomon Desta, Asfaw Negassa, Kidus Nigussie, et al. (2015) Ethiopia Livestock Master Plan, ILRI Project Report. International Livestock Research Institute (ILRI), Nairobi, Kenya.

2. Schwartz HJ (1992) Productive performance and productivity of dromedaries (Camelus dromedarius). Anim Res Dev 35: 85-98.

3. Kahkashan P, Badriah A, Shaista A (2011) Effect of temperature on shelf life, chemical and microbial properties of cream cheese. African Journal of Biotechnology 10: 74.

4. Ogwaro BAH, Gibson M, Whitehead DJ, Hill (2002) Survival of Escherichia coli 0157:H7 in traditional African yoghurt fermentation. International Journal of Food Microbiology 79: 105-112.

5. Mehaia MA (2006) Manufacturing of fresh soft white cheese (Domaiti type) from dromedary milk using ultra-filtration process. Journal Food Technology 42: 206-212.

6. Hailu Y, Seifu E, Yilma Z (2014) Clotting activity of camel milk using crude extracts of ginger (Zingiber officinale) rhizome. Afr J Food Sci Technol 5(3): 90-95.

7. Hailu Y, Hansen EB, Seifu E, Eshetu M, Ipsen R, et al. (2018) Rheological and sensory properties and aroma compounds formed during ripening of soft-brined cheese made from camel milk. International Dairy Journal. 81: 122-130.

8. Kappeler SR, Vanden Brink HJM, Farah Z, Hansen EB, Johansen E, et al. (2006) Characterization of recombinant camel chymosin reveals superior properties for the coagulation of bovine and camel milk. Journal Biochemistry Biophysics Res Commun 342: 647-654.

9. Salvador A, Fiszman SM (2004) Textural and sensory characteristics of whole and skimmed. A set-type yogurt during long storage. Journal of Dairy Science 87: 4033-4041.

10. Choi SH (2004) Scientific consideration in determining shelf life of market milk. Journals Korean Dairy Technology Science, 22: 27-35.

11.AOAC (Association of Official Analytical Chemists) (1995) Official methods of analysis. ( $16^{\text {th }}$ edn), Association of Official Analytical Chemists. Washington, USA.

12. Ousman AO, El Owni Omer IA, Hamid (2008) Effect of Storage Period on Weight Loss, Chemical Composition, Microbiological and Sensory Characteristics of Sudanese White Cheese (Gibna Bayda). Pakistan Journal of Nutrition 7(1): 75-78.

13. Bourne MC (1988) Food texture and viscosity: Concept and measurement. Academic Press, New York, USA.

14. SAS (1999) Statistical Analysis Software (SAS) system for windows, version 9.1. Cary, SAS Institute Inc, North Carolina, USA.
15. Alaoui Ismaili M, Saidi B, Zahar M, Hamama A, Ezzaier R (2016) Composition and microbial quality of raw camel milk produced in Morocco. Journal of the Saudi Society of Agricultural Science 18(1): 17-21.

16. Al-haj OA, Al-Kanhal HA (2010) Compositional, technological and nutritional aspects of Dromedary camel milk-a review. International Dairy Journal 20: 811-821.

17. Bilal AM (2000) Effect of Partial Substitution of Soymilk on the Chemical Composition and Sensory Characteristics of White Soft Cheese. Thesis, University of Khartoum, Sudan.

18. Abdel Razig AK (1996) Production of White Soft Cheese from Different Milk Sources. MSc. Thesis, University of Khartoum, Sudan.

19. Akhtar S, Anjum FM, Rehman S (2005) Effect of fortification on physicochemical and microbiological stability of whole wheat flour. Journal of Food Chemistry, 110: 113-119.

20. Walstra P, Geurts T, Jellema A, Van Boekel M (1999) Dairy Technology. Principles of milk properties and processes. Marcel Dekker, inc, New York, USA.

21. El-Owni OA, Hamid OI (2009) Effect of storage period on weight loss, chemical composition, microbiological and sensory characteristics of Sudanese white cheese (Gibna Bayeda). Paks. Journals of Nutrition 7: 75-80.

22. Nuser SNM (2001) The Effect of Cooking and Vacuum Packaging on the Quality of White Soft Cheese. M.Sc. Thesis University of Khartoum, Sudan.

23. Perveen K, Badriah Alabdulkarim, Shaista Arzoo (2011) Effect of temperature on shelf life, chemical and microbial properties of cream cheese. African Journal of Biotechnology 10(74): 16929-16936.

24. Shobha D, Prasanna K, Puttaramanaik MK, Sreemasetty TA (2011) Effect of antioxidant on the shelf life of quality protein maize flour. India Journal Fundamental Applied Life Science 1: 129-140.

25. Aly AS, Galal EA (2002) Effect of Milk pretreatment on the keeping Quality of Domiati cheese. Pakistan Journal of Nutrition, 1(3): 132-136.

26. Van Hekken DL, Tunick MH, Tomasula PM, Molina Corral FJ, Gardea AA (2007) Mexican queso chihuahua: Rheology of fresh cheese. International Journal of Dairy Technology 60: 5-12.

27. Delgado FJ, Crespo JG, Cava R, Ramírez R (2011) Proteolysis, texture and color of a raw goat Milk cheese throughout the maturation. European Food Research Technology 233(6): 483-488.

28. Romani S, Sacchetti G, Pittia P, Pinnavaia GG, Dalla Rosa M (2002) Physical, chemical, textural and sensorial changes of portioned Parmigiano Reggiano cheese packed under different conditions. Food Science Technology International 8: 203-211.

29. Fox PF, Guinee TP, Cogan TM, Mc Sweeney PLH (1988) Fundamentals of Cheese Science. Aspen Publishers Inc Gaithersburg, Maryland, USA.

30. Gacula MC, Singh J, Bi J, Alan S (2009) Statistical methods in food and consumer research. Elsevier, Amsterdam, Netherlands.

31. Kurtu MY (2003) Certain aspects of the Dairy system in the Harar milk shed, Eastern Ethiopia. Thesis presented to the School of Graduate Studies of the Universities of the Free State, South Africa. 
This work is licensed under Creative Commons Attribution 4.0 License

DOI: 10.19080/JDVS.2019.10.555794

\section{Your next submission with Juniper Publishers} will reach you the below assets

- Quality Editorial service

- Swift Peer Review

- Reprints availability

- E-prints Service

- Manuscript Podcast for convenient understanding

- Global attainment for your research

- Manuscript accessibility in different formats ( Pdf, E-pub, Full Text, Audio)

- Unceasing customer service

Track the below URL for one-step submission https://juniperpublishers.com/online-submission.php 